\title{
Assessment of heavy metals pollution in sediment of Citarum River, Indonesia
}

\author{
Mutia Oktarina P. Yenny ${ }^{\mathrm{a}}$, Arief Hartono ${ }^{\mathrm{b}}$, Syaiful Anwar ${ }^{\mathrm{b}}$, Yumei Kang ${ }^{\mathrm{c}}$ \\ ${ }^{\text {a }}$ Soil Science Study Program, Graduate School IPB University, Bogor-West Java 16680, Indonesia \\ ${ }^{\mathrm{b}}$ Department of Soil Science and Land Resource, Faculty of Agriculture, IPB University, Bogor-West Java 16680, Indonesia \\ [+628121108782] \\ ${ }^{\mathrm{c}}$ Faculty of Agriculture, Kochi University, Kochi 783-8502, Japan
}

\section{Article Info:}

Received: 22 - 08 - 2020

Accepted: 07 - 12 - 2020

\section{Keywords:}

Bioavailability, chemical fractions, risk assessment

Corresponding Author: Arief Hartono

Department of Soil Science and Land Resource, Faculty of Agriculture, IPB University, Bogor-West Java 16680, Indonesia

Phone. +628121108782

Email :

hartono@apps.ipb.ac.id

\begin{abstract}
Heavy metals have been reported to accumulate in the sediment of Citarum River. The measurement of total heavy metals may not be able to provide information about the exact dimension of pollution, thus the determination of different fractions assumed great importance. This study was performed to determine chemical fractions of heavy metals $(\mathrm{Cu}, \mathrm{Ni}, \mathrm{Cr}$, $\mathrm{Pb}$, and $\mathrm{Cd}$ ) in sediment collected at 8 locations from Citarum River. The sequential extraction procedure was used to extract heavy metals in watersoluble, acid-soluble, $\mathrm{MnO}$ occluded, organically bound, $\mathrm{FeO}$ occluded, and residual fraction in sediment. Bioavailability and potential ecological risk level of heavy metals were evaluated based on bioavailability factor (BF) and risk assessment code (RAC) method. The results showed that $\mathrm{Cu}, \mathrm{Ni}, \mathrm{Cr}$ were mostly in residual form, indicate those from geological sources. $\mathrm{Cu}$ had low bioavailability and no risk in all sediment samples of Citarum River. $\mathrm{Ni}$ and $\mathrm{Cr}$ each were found to have risk at 2 locations. $\mathrm{Pb}$ and $\mathrm{Cd}$ were found dominantly in non-residual fractions, suggest those from anthropogenic sources. $B F$ and RAC analysis of $P b$ and $C d$ suggest that there is a potential risk to the aquatic environment.
\end{abstract}

How to cite (CSE Style $8^{\text {th }}$ Edition):

Yenny MOP, Hartono A, Anwar S, Kang Y. 2020. Assessment of heavy metals pollution in sediment of Citarum River, Indonesia. JPSL 10(4): 584-593. http://dx.doi.org/10.29244/jpsl.10.4.584-593.

\section{INTRODUCTION}

Citarum watershed is located in western part of Java island, and its basin covers $5960 \mathrm{~km}^{2}$. The total length of the main river is about $315 \mathrm{~km}$ and flows from its water sources from Mount Wayang to the Java Sea in the north. The greater part of the basin is highly productive land. More than $56 \%$ of the area is used for agricultural purposes, while the rest of the area is covered by forest $(27.4 \%)$, industry $(7.9 \%)$, settlements (7.4\%), fishpond (1.3\%) and other miscellaneous uses (5.7\%) (Bukit, 1995).

Besides giving great benefit, Citarum River has an equally great tendency for pollution. High pollution makes Citarum River has been declared as the most polluted river in the world by World Bank version, due to toxic waste that enters Citarum River (IDN Times, 2018). To illustrate how dirty the Citarum River is, at some places we cannot even see the water. Its surface is completely covered by high amount of waste, trash, and dead animals floating on it. Toxic metals have been reported to accumulate in the both water and aquatic sediment of Citarum River. In water (midle segment of the Citarum River), several heavy metals were found such as Cd $0.01 \mathrm{mg} / \mathrm{kg}$, Cr $0.107 \mathrm{mg} / \mathrm{kg}, \mathrm{Zn} 0.109 \mathrm{mg} / \mathrm{kg}, \mathrm{Hg} 0.00001 \mathrm{mg} / \mathrm{kg}, \mathrm{Cu} 0.024 \mathrm{mg} / \mathrm{kg}, \mathrm{Pb} 0.07$ $\mathrm{mg} / \mathrm{kg}$ and As $0.00079 \mathrm{mg} / \mathrm{kg}$ (Septiono et al., 2016). According to Muhajir et al. (2004) accumulation of 
heavy metals in sediment in the downstream of Citarum River, Jakarta bay, consists of $\mathrm{Pb} 14.7 \mathrm{mg} / \mathrm{kg}, \mathrm{Cd}$ $0.041 \mathrm{mg} / \mathrm{kg}, \mathrm{Cu} 16.22 \mathrm{mg} / \mathrm{kg}$, Zn $90.52 \mathrm{mg} / \mathrm{kg}$, and Ni $10.21 \mathrm{mg} / \mathrm{kg}$.

Sediment is crucial components of the water environment which acts as pollutant sinks, therefore investigating contamination in sediment is very important. There have been many studies about heavy metals in sediment (Paundanan et al., 2015; Syahminan et al., 2015). In sediment, heavy metals can be present in various chemical forms. Jain (2004) noted that each form of heavy metals have different bioavailability and toxicity as the environmentalists are rightly concerned about the exact forms of metal present in the aquatic environment. There have been many studies on the fractionation and bioavailability of heavy metals in sediment. There is no recent information about heavy metal pollution level and fractionation on sediment from Citarum River, Indonesia.

The objectives of this research were: (1) to quantify and assess spatial variations of studied elements copper $(\mathrm{Cu})$, chromium $(\mathrm{Cr})$, nickel $(\mathrm{Ni})$, lead $(\mathrm{Pb})$, and cadmium $(\mathrm{Cd})$ in sediment of Citarum River and (2) to determine the bioavailability and the potential ecological risk level based on the bioavailability factor (BF) and risk assessment code (RAC) method to support the management of heavy metals contamination in Citarum River. Sequential extraction was used for evaluating particular metal-sediment phase associated.

\section{MATERIALS AND METHODS}

\section{Time and Location}

Sediment samples were collected only in one period that was on May $14^{\text {th }}$ to $18^{\text {th }}, 2018$ at 8 sampling locations differentiated as upstream (Cisanti and Wangisara), middle (Koyod, Cisurug, and Nanjung) and downstream (Jatiluhur, Tunggak Jati, and Walahar) area of Citarum River as shown in Figure 1. Laboratory analysis was conducted at soil chemistry laboratory, IPB University and Laboratory of soil environmental science, Kochi University, Japan.

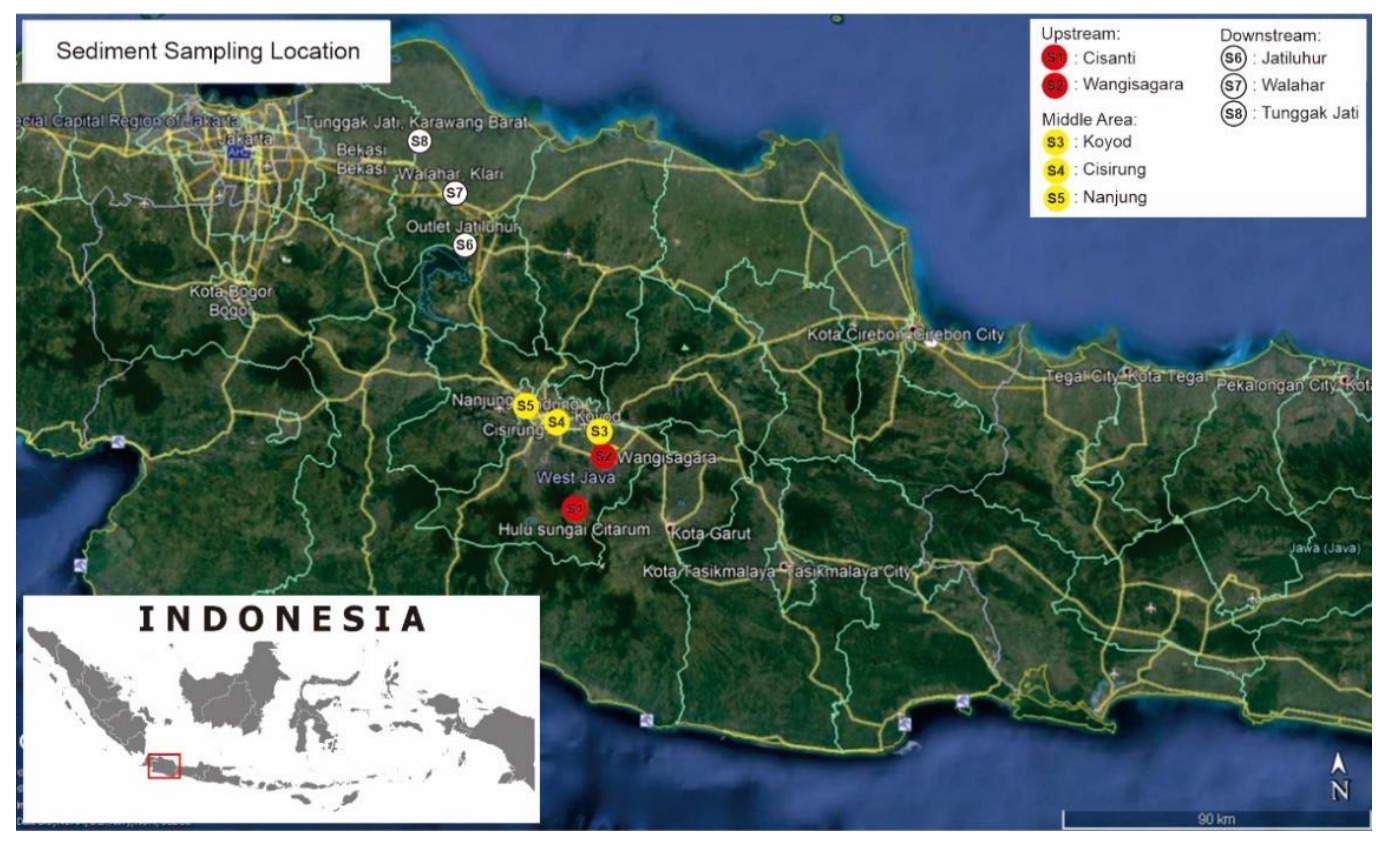

Figure 1 Distribution of sediment sampling point

\section{Sediment Sampling}

At each location, sediment sample was taken in the composite manner from three sampling points to a depth of $60 \mathrm{~cm}$ from the sediment surface. The composite samples were air dried, sieved to pass $2 \mathrm{~mm}$ and stored for analyses. 


\section{Physico-chemical Properties Analyses}

The physico-chemical properties of the studied sediment analyzed namely $\mathrm{pH}$, Cation Exchange Capacity (CEC), total carbon (TC), and texture. Potentiometric method using a glass electrode was used to measure the sediment $\mathrm{pH}$. CEC was estimated using $1 \mathrm{M}$ Ammonium acetate $\left(\mathrm{NH}_{4} \mathrm{OAc}\right)$ solution at $\mathrm{pH}$ 7.0. Total carbon and texture of the studied sediment were analyzed using N-C Analyzer and pipette method, respectively.

\section{Heavy Metal Fractionation Analysis}

Chemical forms of heavy metals were estimated using sequential extraction method reported by Iwasaki et al. (1997) with some modification (Phuong et al., 2010) as shown in Table 1. The supernatant was analyzed using AAS Shimadzu AA-6800.

Table 1 Sequential extraction procedure employed for the fractionation of heavy metals

\begin{tabular}{|c|c|c|c|}
\hline Fractions & Reagents & $\begin{array}{l}\text { Sample/Solution } \\
\text { Ratio }\end{array}$ & Condition \\
\hline Water-soluble (Ws) & Deionized water & $1: 5$ & Shake 2 hours \\
\hline Exchangeable (Exc) & $\begin{array}{l}1.0 \mathrm{~mol} / \mathrm{L} \mathrm{CH}_{3} \mathrm{COONH}_{4}(\mathrm{pH} \\
7.0)\end{array}$ & 1: 10 & Shake 2 hours \\
\hline Acid soluble (Aci) & $\begin{array}{l}25 \mathrm{~g} / \mathrm{L} \mathrm{CH}_{3} \mathrm{COOH} \\
(\mathrm{pH} 2.6)\end{array}$ & 1: 10 & Shake 6 hours \\
\hline $\begin{array}{l}\text { Mn oxide occluded } \\
(\mathrm{MnO})\end{array}$ & $\begin{array}{l}0.1 \mathrm{~mol} / \mathrm{L} \mathrm{NH}_{2} \mathrm{OH} . \mathrm{HCl}(\mathrm{pH} \\
2.0)\end{array}$ & 1: 10 & Shake 0.5 hour \\
\hline Organically bound (OM) & $\begin{array}{l}0.1 \mathrm{~mol} / \mathrm{L} \mathrm{Na}_{4} \mathrm{P}_{2} \mathrm{O}_{7} \\
(\mathrm{pH} 10)\end{array}$ & 1: 50 & Shake 24 hours \\
\hline Fe oxide occluded $(\mathrm{FeO})$ & $\begin{array}{l}0.175 \mathrm{~mol} / \mathrm{L}\left(\mathrm{NH}_{4}\right)_{2} \mathrm{C}_{2} \mathrm{O}_{4}, \\
0.1 \mathrm{~mol} / \mathrm{L} \mathrm{H}_{2} \mathrm{C}_{2} \mathrm{O}_{4}, \\
0.1 \mathrm{~mol} / \mathrm{L} \text { ascorbic acid } \\
(\mathrm{pH} \mathrm{3.1)}\end{array}$ & 1: 50 & $\begin{array}{l}\text { Shake } 4 \text { hours, then } \\
\text { stir occasionally in } \\
\text { boiling water for } 0.5 \\
\text { hour }\end{array}$ \\
\hline Residual (Res) & $\mathrm{H}_{2} \mathrm{SO}_{4}: \mathrm{HNO}_{3}: \mathrm{HClO}_{4}(1: 5: 20)$ & & \\
\hline
\end{tabular}

\section{Data Analysis}

\section{Total Content of Heavy Metals}

Total content of heavy metals was calculated by the total sum of the fractions. To assess the environmental pollution, total content of heavy metals was compared with freshwater sediment quality guidelines for heavy metals.

\section{Fractionation Analysis to Identify Potential Source of Heavy Metals}

Fractionation of heavy metals were demonstrated in relative percentage. The equation is shown below:

$$
\mathrm{C}(\%)=\frac{C_{\text {fraction }}}{C_{\text {total }}} \times 100
$$

Were $\mathrm{C}_{\text {fraction }}$ and $\mathrm{C}_{\text {total }}$ are the concentration of heavy metals in each fraction and the total concentration of heavy metals in sediment. 
Fractionation is used to estimate the sediment metal source contributed by anthropogenic activities or by geochemical sources. Anthropogenic inputs were important sources of labile fractions (non-residual) of heavy metals in sediments, while residual fraction was mainly controlled by natural source (Liang et al., 2018).

\section{Bioavailability Factor (BF) and Risk Assessment Code (RAC)}

Heavy metal bioavailability depends more on the proportions of the different fractions than on the total concentration (Yang et al., 2017). Bioavailability factor was described by Bielicka-giełdoń et al. (2013). Bioavailability factor allows for the determination of possibly toxic elements in sediment. BF was calculated by following formula:

$$
\mathrm{BF}=\frac{C_{\text {bio }}}{C_{\text {total }}}
$$

Where $\mathrm{C}_{\text {bio }}$ and $\mathrm{C}_{\text {total }}$ are the concentration of bioavailable heavy metals and the total concentration of heavy metals in sediment. Bioavailable heavy metals are those extracted in Ws, Exc, Aci, MnO, OM, and $\mathrm{FeO}$ fraction (non-residual fraction).

Risk assessment code (RAC) can be used to assess the risks and mobility of the non-stable chemical fractions of heavy metals in the sediment. In this study, risk assessment code based on the values of heavy metals in water soluble and exchangeable fraction. According to Basta et al. (2005) cationic heavy metals in water soluble and ion exchangeable forms are available to plants.

\section{RESULTS AND DISCUSSION}

\section{Physico-chemical Properties of Sediment}

Sediment physico-chemical properties such as $\mathrm{pH}, \mathrm{CEC}$, total carbon (TC), and textural properties is shown in Table 2. Sediment characterized by $\mathrm{pH}$ varied from slightly acidic to alkaline (5.73-7.45), with the highest value at Jatiluhur. The acidity $(\mathrm{pH})$ distribution among the studied sediment was influenced by total carbon content.

Table 2 Physico-chemical properties of sediment

\begin{tabular}{ccccc}
\hline Locations & $\mathrm{pH}$ & $\mathrm{CEC}(\mathrm{cmol}(+) / \mathrm{kg})$ & $\mathrm{TC}(\mathrm{g} / \mathrm{kg})$ & Texture \\
\hline Cisanti & 5.7 & 38.5 & 28.0 & Clay loam \\
Wangisagara & 6.9 & 23.8 & 22.1 & Sandy clay loam \\
Koyod & 6.5 & 19.3 & 14.1 & Sandy clay loam \\
Cisirung & 6.8 & 27.0 & 15.0 & Sandy clay loam \\
Nanjung & 6.7 & 28.0 & 21.9 & Sandy clay loam \\
Jatiluhur & 7.6 & 13.5 & 5.0 & Sandy clay loam \\
Walahar & 7.3 & 28.6 & 8.1 & Clay \\
Tunggak Jati & 7.4 & 31.2 & 10.3 & Clay \\
\hline
\end{tabular}

All sediment varied in total carbon from $5.04 \mathrm{~g} / \mathrm{kg}$ to $27.97 \mathrm{~g} / \mathrm{kg}$. Cisanti, upstream area, has the highest total carbon. Wetland and riparian environments are characterized by high organic carbon concentrations in the form of animal and plant detritus. A high percentage of clay in texture analysis was usually observed at most of sampling sites. The distribution pattern of sediment physico-chemical properties was a combined result of sediment input, depositional process and hydrodynamic conditions (Astuti and Rahmanto, 2015). In this study, physico-chemical properties analysis shows the heterogeneity of the studied sediment. 


\section{Distribution of Total Heavy Metals}

Total content of heavy metals in sediment of Citarum River displayed different ranges among elements as shown in Table 3. Total content of heavy metals in sediment of Citarum River were compared with freshwater sediment quality guidelines for heavy metals.

Table 3 Total content of heavy metals in the studied sediment.

\begin{tabular}{lccccc}
\hline \multirow{2}{*}{ Locations } & \multicolumn{5}{c}{ Total Content $(\mathrm{mg} / \mathrm{kg})$} \\
\cline { 2 - 6 } & $\mathrm{Cu}$ & $\mathrm{Cr}$ & $\mathrm{Ni}$ & $\mathrm{Pb}$ & $\mathrm{Cd}$ \\
\hline Cisanti & 47.5 & 8.8 & 10.9 & 16.3 & 0.400 \\
Wangisagara & 49.8 & 7.5 & 14.2 & 12.3 & 0.196 \\
Koyod & 44.5 & 12.9 & 15.2 & 11.7 & 0.325 \\
Cisirung & 54.5 & 9.1 & 13.0 & 17.0 & 0.418 \\
Nanjung & 59.5 & 13.0 & 13.5 & 22.9 & 0.464 \\
Jatiluhur & 11.2 & 18.2 & 14.2 & 26.8 & 0.426 \\
Walahar & 18.1 & 10.1 & 13.3 & 29.2 & 0.377 \\
Tunggak Jati & 26.6 & 10.9 & 12.7 & 20.9 & 0.583 \\
Threshold (Environment & 35.7 & 37.3 & 18.0 & 35.0 & 0.596 \\
Canada 1994) & & & & & \\
Default guideline value (Australian & 65 & 80 & 21 & 50 & 1.5 \\
Government Initiative 2018) & & & & & \\
\hline
\end{tabular}

Copper was found in higher content in upstream and middle area, particularly in Cisanti which described unpolluted area of Citarum River. Total content of $\mathrm{Cu}$ in Cisanti, Wangisagara, Koyod, Cisurung, and Nanjung were above threshold effect levels for freshwater sediment. However, the total concentration of $\mathrm{Cu}$ in these locations did not exceed value according to default guideline value for toxicant in sediment. $\mathrm{Cr}$, $\mathrm{Ni}, \mathrm{Pb}$, and $\mathrm{Cd}$ content in sediment of Citarum River did not exceeded the permissible limits of threshold effect levels and default guideline value for toxicant in sediment.

Enrichment of heavy metals over and above to their respective background values indicates their accumulation either by lithogenic and/or anthropogenic sources. Sediment with high total heavy metal concentration may be relatively harmless to organism if conditions are such that desorption or dissolution of metals from sediment is restricted. Conversely, sediment with lower total heavy metal concentrations may affect organism to a great extent if sediment conditions are optimal for dissolution or desorption.

\section{Heavy Metal Fractionation}

Heavy metal fractionation analysis is shown in Figure 2. The percentage of $\mathrm{Cu}, \mathrm{Cr}, \mathrm{Ni}, \mathrm{Pb}$, and $\mathrm{Cd}$ in water soluble and exchangeable fraction occurred only in trace amounts among the sediment of Citarum River. $\mathrm{Cu}, \mathrm{Cr}$, and $\mathrm{Ni}$ were mainly found in residual form. Singh et al. (2005) showed that the greater the percentage of heavy metal present in residual form, the smaller the pollution of the zone.

The concentration of $\mathrm{Cu}, \mathrm{Cr}$, and $\mathrm{Ni}$ in this study mainly depends on the parent material from which the soil and sediment was formed. Though total content of $\mathrm{Cu}$ in upstream and middle area were above the acceptable limit, it was in the most stable fraction. This study confirmed that total content of heavy metal alone is not able to evaluate the ecological risk of heavy metals.

Alloway (2012) found that possible $\mathrm{Cu}$ natural origin is $\mathrm{Cu}$ from the basalt parent material which contain $\mathrm{Cu} 90 \mathrm{mg} / \mathrm{kg}$. According to Ratman and Gafoer (1998), geological properties in upstream area of Citarum River is characterized by andesite-basalt material. This suggests the source of high amount of $\mathrm{Cu}$ in upstream area of the river. Cu was also found in organic matter occluded fraction. Chakraborty et al. (2016) 
also reported that the non-residual $\mathrm{Cu}$ was more associated with organic matter in the sediment of Western Continental Margin of India. Cu is known to form strong bonds with humic substances (Stevenson, 1994).

Other study carried out in Spain and China (Morillo et al., 2004; Yuan et al., 2004) also showed that Cr was found mainly in the residual fraction in all sediment samples. On the other hand, in non-residual fraction, Cr mainly associated with Fe oxides. Chromium in household and textile industry waste (Das et al., 2015; Alam et al., 2018) in Citarum River may influence Cr content in non-residual form. Figure 2 shows Ni in non-residual form increased from upstream to the downstream area, though there was no difference in the total content of Ni. This indicate that Ni content in upstream and middle area (from Cisanti to Nanjung) are natural input. Conversely, $\mathrm{Ni}$ in downstream area (from Jatiluhur to Tunggak Jati) are mostly from anthropogenic sources and enrichment factor.

In contrast, sediment $\mathrm{Pb}$ and $\mathrm{Cd}$ concentrations in Citarum River display a much different pattern from those of other metals. According to Figure 2 measurement of the proportions of $\mathrm{Pb}$ and $\mathrm{Cd}$ in the seven fractions showed that non-residual form was dominant. This suggests that $\mathrm{Pb}$ and $\mathrm{Cd}$ are linked with human activities in Citarum River. Cadmium contamination linked to anthropogenic activities was found in all segment of Citarum River, including Cisanti as upstream area. It is known that there have been agricultural activities in upstream area of Citarum River. Besides industrial waste, commercial inorganic $\mathrm{P}$ fertilizers contribute to heavy metals contamination to the environment including river sediment (Mary et al., 2018). Phosphate fertilizer contains some heavy metals at various amount such as $\mathrm{Cd}(0.1-170 \mathrm{mg} / \mathrm{kg})$ and $\mathrm{Pb}(40-2000 \mathrm{mg} / \mathrm{kg}$ ) (Setyorini, 2003). Thus, Cisanti as upstream area cannot be used as a benchmark of unpolluted area of Citarum River.
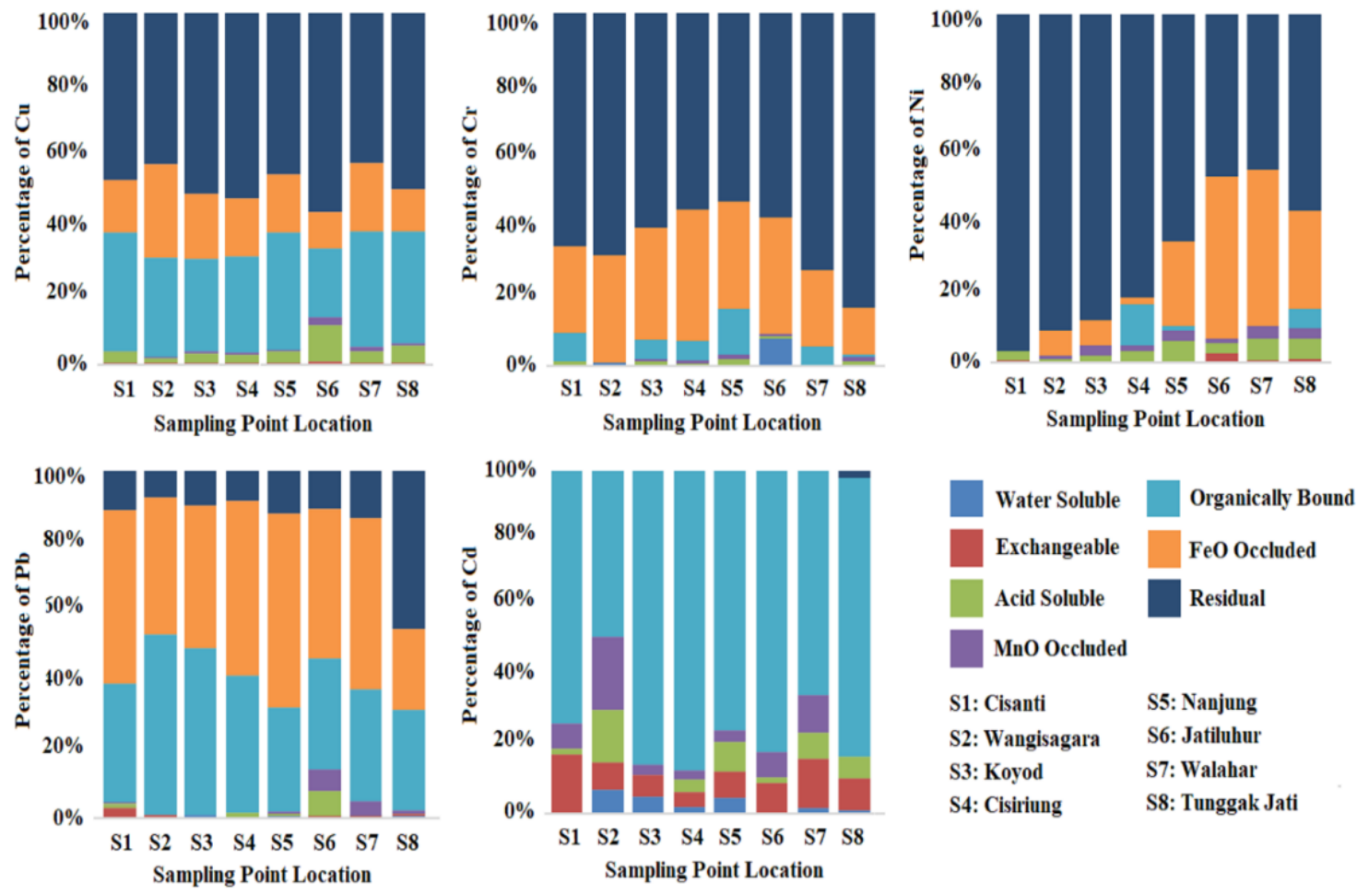

Figure 2 Percentage of $\mathrm{Cu}, \mathrm{Cr}, \mathrm{Ni}, \mathrm{Pb}$, and $\mathrm{Cd}$ in each fraction

$\mathrm{Pb}$ was found dominantly in $\mathrm{FeO}$ fraction except in Tunggak Jati. Chakraborty et al. (2017) showed that the positive correlation between $\mathrm{Pb}$ and $\mathrm{Fe}$ denotes that, the $\mathrm{Fe}$ oxy hydroxide is primary hosting phase for non-residual fraction of $\mathrm{Pb}$ in sediment. Heavy metals in $\mathrm{FeO}$ fraction are those bound to hydrous oxides of iron, Fe oxides scavenge transition and heavy metals in soil, sediment, and wastes. Organically bound fraction ranked second to the $\mathrm{FeO}$ fraction. Organic materials appear to reduce the availability of $\mathrm{Pb}$. $\mathrm{The} \mathrm{Fe}$ Mn oxides and organic matters have scavenging effect for heavy metals, especially $\mathrm{Pb}$ (Duan et al., 2010). 
Cadmium was mostly occluded by organic matter. Soil organic matter influences Cd bioavailability. In spite of soil with higher organic matter have higher cation exchange capacity, heavy metals are probably translocated as metal-organic complexes (Egli et al., 2010). Heavy metal associated with organic compounds can remain in the sediment long time until they are released by decomposition processes or oxidizing agents, leading to their complexation and bioaccumulation (Kennedy et al., 1997).

\section{Bioavailability Factor (BF)}

Bioavailability factor of heavy metals in the studied sediment is described in Table 4. BF of $\mathrm{Cu}$ was found from 0.43 to 0.57 , indicating the mobilization of approximately $50 \% \mathrm{Cu}$ in the studied sediment. The possibly mobility $\mathrm{Cr}$ was recorded ranging from 0.16 to 0.47 . This reflects the lower bioavailability of $\mathrm{Cr}$. Bioavailability of Ni varied from one location to another. Ni in sediment from upstream and middle area had low mobility (>20\%), whereas more than $40 \%$ of $\mathrm{Ni}$ were in bioavailable form at downstream area of Citarum River.

Table 4 Bioavailability factor (BF) of heavy metals in sediment from Citarum River

\begin{tabular}{clllll}
\hline \multirow{2}{*}{ Locations } & \multicolumn{5}{c}{ Bioavailability Factor (BF) } \\
\cline { 2 - 6 } & $\mathrm{Cu}$ & $\mathrm{Cr}$ & $\mathrm{Ni}$ & $\mathrm{Pb}$ & $\mathrm{Cd}$ \\
\hline Cisanti & 0.53 & 0.34 & 0.04 & 0.89 & 1.00 \\
Wangisagara & 0.57 & 0.32 & 0.09 & 0.93 & 1.00 \\
Koyod & 0.49 & 0.39 & 0.12 & 0.91 & 1.00 \\
Cisirung & 0.48 & 0.44 & 0.19 & 0.92 & 1.00 \\
Nanjung & 0.54 & 0.47 & 0.35 & 0.89 & 1.00 \\
Jatiluhur & 0.43 & 0.42 & 0.54 & 0.90 & 1.00 \\
Walahar & 0.57 & 0.27 & 0.56 & 0.87 & 1.00 \\
Tunggak Jati & 0.50 & 0.16 & 0.44 & 0.55 & 0.98 \\
\hline
\end{tabular}

The $\mathrm{BF}$ of $\mathrm{Pb}$ showed relatively higher compare to $\mathrm{Cu}, \mathrm{Cr}$, and $\mathrm{Ni}$ in all locations. Al-mur (2020) stated that high levels of heavy metals bioavailability factor indicate their potential toxicity and that they could be easily released into the environment and ingested by organisms, thereby entering the food chain. The BF of $\mathrm{Cd}$ was the highest among other heavy metals. Generally, this result illustrated approximately $100 \%$ of $\mathrm{Cd}$ exist in bioavailable form and demonstrates a potential risk to aquatic life. Bioavailability of heavy metals could be mitigated, due to several processes that deactivation of heavy metals (Chen et al., 2019). Heavy metals in exchangeable fraction can be released into the environment when conditions become more acidic. Heavy metals in $\mathrm{FeO}$ fraction also can be released into the environment when a reducing condition develops, promoting a dangerous effect to the environment (Al-mur, 2020).

\section{Risk Assessment Code (RAC)}

From ecological point of view, water soluble and exchangeable fraction may easily be leached in neutral or slightly acidic waters and they may be accumulated by living organisms (Wang et al., 2017). Thus, the fractions may be used for evaluating the potential adverse effects on the organisms. Risk evaluation and the RAC classification can be seen in Table 5. The result of speciation shows that $\mathrm{Cu}$ are not at risk, which means the release of $\mathrm{Cu}$ into solution is undetectable and safe to the environment. $\mathrm{Cr}$ at Wangisagara and Jatiluhur shows low risk, while other locations are not at risk with regard to RAC. Ni falls in the no risk to low-risk criteria. The levels of $\mathrm{Ni}$ do not suggest that there is any serious hazard to the environment. Risk evaluation of $\mathrm{Pb}$ namely no risk to low risk, $\mathrm{Cd}$ are low to medium risk. These conditions indicate that $\mathrm{Pb}$ and $\mathrm{Cd}$ are likely to be harmful to the environment. Risk of heavy metals in sediment of Citarum River are $\mathrm{Cd}>\mathrm{Pb}>\mathrm{Cr}=\mathrm{Ni}>\mathrm{Cu}$. 
Table 5 Risk assessment code (RAC) of heavy metals in sediment from Citarum River

\begin{tabular}{cllllll}
\hline \multirow{2}{*}{ Locations } & \multicolumn{5}{c}{ Risk Assessment Code (RAC) } & Criteria (\%) \\
\cline { 2 - 5 } & $\mathrm{Cu}$ & $\mathrm{Cr}$ & $\mathrm{Ni}$ & $\mathrm{Pb}$ & $\mathrm{Cd}$ & (Singh et al., 2005) \\
\hline Cisanti & 0.6 & 0.0 & 0.9 & 3.0 & 17.4 & No risk <1 \\
Wangisagara & 0.5 & 1.0 & 0.0 & 1.1 & 15.1 & Low risk 1-10 \\
Koyod & 0.5 & 0.0 & 0.0 & 1.1 & 11.2 & Medium risk 11-30 \\
Cisirung & 0.6 & 0.0 & 0.0 & 0.4 & 6.2 & High risk 31-50 \\
Nanjung & 0.7 & 0.0 & 0.0 & 0.8 & 12.3 & Very high risk >50 \\
Jatiluhur & 0.9 & 7.9 & 3.0 & 0.8 & 8.9 & \\
Walahar & 0.5 & 0.0 & 0.8 & 0.5 & 15.9 & \\
Tunggak Jati & 0.5 & 0.0 & 1.2 & 1.3 & 10.2 & \\
\hline
\end{tabular}

\section{CONCLUSION}

$\mathrm{Cu}$ was found exceed the permissible limit in upstream and middle area of Citarum River sediment. Whereas, presence of $\mathrm{Cr}, \mathrm{Ni}, \mathrm{Pb}$, and $\mathrm{Cd}$ in sediment was relatively low compared to the standard. Fractionation analysis showed that $\mathrm{Cu}, \mathrm{Cr}$, and $\mathrm{Ni}$ were mostly in residual form, while $\mathrm{Pb}$ and $\mathrm{Cd}$ were mainly in non-residual form. This results in high bioavailability of $\mathrm{Pb}$ and $\mathrm{Cd} . \mathrm{Cu}$ was not at risk at all locations. Ni displayed a low risk at Jatiluhur and Tunggak Jati, $\mathrm{Cr}$ was at low risk in Wangisagara and Jatiluhur, while other locations were not at risk. Risk analysis of $\mathrm{Pb}$ and $\mathrm{Cd}$ in the studied sediment suggested that there was a potential risk to the environment.

\section{ACKNOWLEDGMENTS}

This work was performed under the projects of Indonesian Ministry of Environment and Forestry, and all laboratory analysis was funded by SUIJI (Six Universities Initiative Japan Indonesia) Program.

\section{REFERENCES}

Al-mur BA. 2020. Geochemical fractionation of heavy metals in sediments of the Red Sea, Saudi Arabia. Oceanologia. 62(1): 31-44. doi: 10.1016/j.oceano.2019.07.001.

Alam O, Wang S, Lu W. 2018. Heavy metals dispersion during thermal treatment of plastic bags and its recovery. J Environ Manage. 212: 367-374. doi: 10.1016/j.jenvman.2018.02.034.

Alloway BJ. 2012. Heavy Metals in Soils: Trace Metals and Metalloids in Soils and their Bioavailability. New York (US): Springer.

Astuti N, Rahmanto D. 2015. Analisis erosi dan sedimen di catchment area sungai Hauran menggunakan model AGNPS (Agricultural Non Point Source Pollution Model). J Fis FLUX. 12(1): 31-42.

Australian Government Initiative. 2018. Default Guideline Value for toxicant in sediment, Australia. [Downloaded on 2020 January $20^{\text {th }}$ ]. Available on: https://www.waterquality.gov.au/anzguidelines /guidelinevalues/default/sedimentquality-toxicants.

Basta NT, Ryan JA, Chaney RL. 2005. Trace element chemistry in residual-treated soil: Key concepts and metal bioavailability. J Environ Qual. 34: 49-63.

Bielicka-giełdoń A, Ryłko E, Żamojć K. 2013. Distribution, bioavailability and fractionation of metallic elements in allotment garden soil using the BCR sequential extraction procedure. Pol J Environ Stud. 22(4) :1013-1021.

Bukit NT. 1995. Water quality conservation for the Citarum River in West Java. Wat Sci Tech. 31(9): 1-10. doi: 10.1016/0273-1223(95)00400-H.

Chakraborty P, Chakraborty S, Jayachandran S, Madan R. 2016. Effects of bottom water dissolved oxygen variability on copper and lead fractionation in the sediments across the oxygen minimum zone, 
western continental margin of India. Sci Total Environ. 1-10. doi: 10.1016/ j.scitotenv.2016.05.125.

Chakraborty S, Chakraborty P, Sarkar A, Nath BN. 2017. Kinetic and equilibrium based fractionation study of $\mathrm{Pb}$ in continental shelf sediment of India. Mar Pollut Bull. 123(1-2): 188-196. doi: 10.1016/ j.marpolbul.2017.08.063.

Chen X, Zhao Y, Zeng C, Li Y, Zhu L, Wu J, Chen J. 2019. Assessment contributions of physicochemical properties and bacterial community to mitigate the bioavailability of heavy metals during composting based on structural equation models. Bioresour Technol. 289: 1-9. doi: 10.1016/j.biortech .2019.121657.

Das AK, Hossain A, Hasan Z. 2015. Heavy metals concentration in textile and garments industries wastewater of Bhaluka industrial area, Mymensingh, Bangladesh. Curent World Environ. 10(1): 6166.

Duan L, Song J, Xu Y, Li X, Zhang Y. 2010. The distribution, enrichment and source of potential harmful elements in surface sediments of Bohai Bay, North China. J Hazard Mater. 183(1-3): 155-164. doi: 10.1016/j.jhazmat.2010.07.005.

Egli M, Sartori G, Mirabella A, Giaccai D, Favilli F, Scherrer D, Krebs R, Delbos E. 2010. The influence of weathering and organic matter on heavy metals lability in silicatic, Alpine soils. Sci Total Environ. 408(4): 931-946. doi: 10.1016/j.scitotenv.2009.10.005.

Environment Canada. 1994. Interim Sediment Quality Assessment Values. Ottawa (US): Ecosystem Conservation Directorate, Environment Canada.

IDN Times. 2018. Menurut World Bank: Citarum Merupakan Sungai Terkotor di Dunia [Internet]. [Accessed on 2018 May 13 ${ }^{\text {th }}$. Available on: https://science.idntimes.com/discovery/ekasupriyadi/menurut-world-bank-citarum-merupakan-sungai-terkotor-di-dunia-c1c2.

Iwasaki K, Tsuji M, Sakurai K. 1997. Fractionation of copper and manganese in agricultural soils near an abandoned copper mine. Soil Sci Plant Nutr. 43(1): 157-169. doi: 10.1080/00380768.1997.10414724.

Jain CK. 2004. Metal fractionation study on bed sediments of River Yamuna, India. Water Res. 38(3): 569578. doi: 10.1016/j.watres.2003.10.042.

Kennedy VH, Sanchez AL, Oughton DH, Rowland AP. 1997. Use of single and sequential chemical extractants to assess radionuclide and heavy metal availability from soils for root uptake. Analyst. 122: $89-100$.

Liang X, Song J, Duan L, Yuan H, Li X, Li N, Qu B, Wang Q, Xing J. 2018. Source identification and risk assessment based on fractionation of heavy metals in surface sediment of Jiaozhou Bay, China. Mar Pollut Bull. 128: 548-556. doi: 10.1016/j.marpolbul.2018.02.008.

Mary J, Karthik C, Ganesh R, Kumar SS, Prabakar D, Kadirvelu K, Pugazhendhi A. 2018. Biological approaches to tackle heavy metal pollution: A survey of literature. J Environ Manage. 217: 56-70. doi: 10.1016/j.jenvman.2018.03.077.

Morillo J, Usero J, Gracia I. 2004. Heavy metal distribution in marine sediments from the southwest coast of Spain. Chemosphere. 55(3): 431-442. doi: 10.1016/j.chemosphere.2003.10.047.

Muhajir, Edward, Ahmad F. 2004. Akumulasi logam berat $\mathrm{Pb}, \mathrm{Cd}, \mathrm{Cu}, \mathrm{Zn}$ dan $\mathrm{Cr}$ dalam sedimen di muara sungai Cisadane, Ciliwung dan Citarum, Teluk Jakarta. J Ilm Sorihi. 3(1): 83-98.

Paundanan M, Riani E, Anwar S. 2015. Kontaminasi logam berat merkuri (Hg) dan timbal $(\mathrm{Pb})$ pada air, sedimen dan ikan selar tetengkek (Megalaspis cordyla L) di Teluk Palu, Sulawesi Tengah. JPSL. 5(2): 161-168. doi: 10.19081/jpsl.5.2.161.

Phuong NM, Kang Y, Sakurai K, Iwasaki K, Kiren NC, Noi NV, Son LT. 2010. Levels and chemical forms of heavy metals in soils from Red River Delta, Vietnam. Water Air Soil Pollut. 207: 319-332. doi: 10.1007/s11270-009-0139-0.

Ratman N, Gafoer S. 1998. Geological Map of Western Part of Jawa: Second Edition. Bandung (ID): Geological Research and Development Centre. 
Septiono MA, Roosmini D, Rachmatiah I, Salami S, Ariesyady HD. 2016. Industrial activities and its effects to river water quality (case study Citarum, Bengawan Solo and Brantas), an evaluation for Java Island as an economic corridor in master plan of acceleration and expansion of Indonesia economic development (MP3EI). The 12th International Symposium on Southeast Asian Water Environment (SEAWE2016); 2016 Nov 28-30; Hanoi, Vietnam.

Setyorini D, Soeparto, Sulaeman. 2003. Kadar logam berat dalam pupuk. In: Prosiding Seminar Nasional Peningkatan Kualitas Lingkungan dan Produk Pertanian: Pertanian Produktif Ramah Lingkungan Mendukung Ketahanan dan Keamanan Pangan. Jakarta (ID): Pusat Penelitian dan Pengembangan Tanah dan Agroklimat, Badan Penelitian dan Pengembangan Pertanian.

Singh KP, Mohan D, Singh VK, Malik A. 2005. Studies on distribution and fractionation of heavy metals in Gomti river sediments — a tributary of the Ganges, India. J Hydrol. 312(1-4): 14-27. doi: 10.1016/j .jhydrol.2005.01.021.

Stevenson FJ. 1994. Humus Chemistry: Genesis, Compositions, Reactions. Second Edition. New York (US): John Wiley and Sons.

Syahminan, Riani E, Anwar S, Rifardi. 2015. Telaahan logam berat $\mathrm{Pb}$ dan $\mathrm{Cd}$ pada sedimen di perairan barat laut Dumai-Riau. JPSL. 5(2): 133-140. doi: 10.19081/jpsl.5.2.133.

Wang Q, Liu R, Men C, Xu F, Guo L, Shen Z. 2017. Spatial-temporal distribution and risk assessment of mercury in different fractions in surface sediments from the Yangtze river estuary. Mar Pollut Bull. 124(1): 1-8. doi: 10.1016/j.marpolbul.2017.07.034.

Yang W, Li X, Pei J, Sun T, Shao D, Bai J, Li Y. 2017. Bioavailability of trace metals in sediment of a recovering freshwater coastal wetland in China's Yellow River Delta, and risk assessment for the macrobenthic community. Chemosphere. 189: 661-671. doi: 10.1016/j.chemosphere.2017.09.103.

Yuan C, Shi J, He B, Liu J, Liang L, Jiang G. 2004. Speciation of heavy metals in marine sediments from the East China Sea by ICP-MS with sequential extraction. Environ Int. 30: 769-783. doi: 10.1016 /j.envint.2004.01.001. 